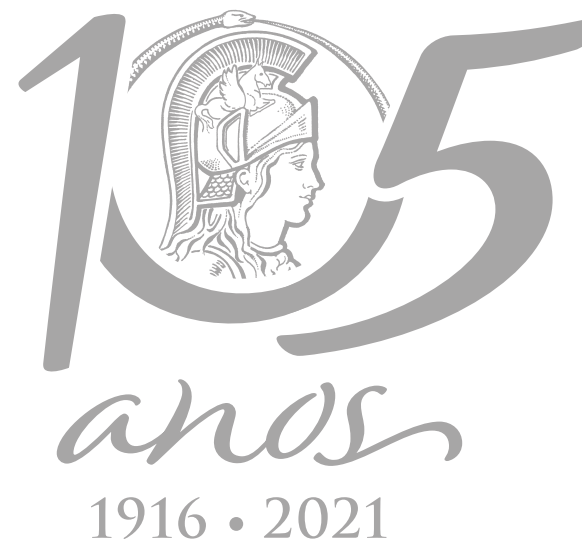

$1916 \cdot 2021$

\title{
ECOSYSTEMS
}

\section{Nutritional and technological potential of Umbu (Spondias tuberosa Arr. Cam.) processing by-product flour}

\author{
VIVIANE L. XAVIER, GEORGE S. FEITOZA, JULYANNE MARIA L. BARBOSA, \\ KATARYNNA S. DE ARAÚJO, MÁRCIA VANUSA DA SILVA, MARIA TEREZA S. \\ CORREIA, MARTHYNA P. DE SOUZA \& MARIA DAS GRAÇAS CARNEIRO-DA-CUNHA
}

\begin{abstract}
Antioxidants present in many fruit residues can play an essential role in the prevention of diseases. The aim of this study was to determine nutritional and mineral composition, fatty acids profile, anti-nutrients, bioactive compounds, antioxidant activity and technological properties of flour from residues generated by umbu fruit processing. Nutritional composition showed high levels of dietary fiber, especially insoluble fiber (56.67\%). The flour can be classified as a good source of calcium, phosphorus and magnesium, and an excellent source of iron, zinc and copper. Palmitic and stearic saturated fatty acids and oleic and linoleic unsaturated fatty acids were identified. No potentially toxic substances were detected. Significant values of ascorbic acid (44.78 mg/100g), carotenoids (463.73 $\mu \mathrm{g} / 100 \mathrm{~g}$ ) and flavonoids (37.85 mg QE/100g) were found, as well as very high levels of phenolic compounds (20357.26 mg GAE/100g). Strong antioxidant activity was detected in the flour by three methods (ABTS, DPPH and FRAP) demonstrating a linear positive correlation between phenolic content and antioxidant activity. The flour showed high absorption of water, oil, emulsifying capacity and emulsion stability presenting a great potential for use in foods, especially meat, bakery and dairy products. These results indicate promising prospects to full use of umbu as a functional ingredient.
\end{abstract}

Key words: anti-nutrient, antioxidant, extractive practice, food waste, seed.

\section{INTRODUCTION}

Caatinga is an exclusively Brazilian biome that occupies $11 \%$ of the national territory. It encompasses the states of Alagoas, Bahia, Ceará, Maranhão, Pernambuco, Paraíba, Rio Grande do Norte, Piauí, Sergipe and northern Minas Gerais. Rich in biodiversity, the caatinga has potential for the conservation of environmental services, sustainable use and bioprospecting which, if well explored, will be decisive for the development of the region and the country (MMA 2020). Brazil has low commercialization of native products, even though they are present throughout the national territory, within its diverse ecosystems. According to the study by the National Supply Company (Conab 2019), the failures in this market occur mainly due to the lack of information in the sector, or not very accurate. Many of the native or non-native fruit species are part of the food diversity in several local communities, however, few scientific studies are available on the nutritional importance, among these the Umbu fruit.

Umbu (Spondias tuberosa Arr. Cam.) is an endemic tropical fruit from semi-arid region of Northeast Brazil. It is a small fruit with yellowishgreen color when ripe, refreshing and acidic 
flavor, velvety texture, rich in vitamin $\mathrm{C}$ and bioactive compounds. In general, it is consumed and commercialized in natura, as frozen pulp, juice, ice cream, sweets, jelly or as the traditional "umbuzada" (fruit pulp cooked with milk and sugar). Popularly known as "umbuzeiro" or "imbuzeiro", umbu tree presents an important role in local economy, mainly during dry season, since it's an alternative income source for the population which survives from umbu extractive practice. The process of harvesting is also a cultural one, since this tradition is handed down from generation to generation (Batista et al. 2015).

Umbu is a climacteric fruit of fast seasonality, whose period of harvest is from December to March. In this period, local population takes advantage of umbu fruit availability for its commercialization in street fairs, supermarkets, and on roadsides. Data on umbu extraction in Brazil showed that production grew $8 \%$ in 2015 over 2014, and in 2016 grew 12.6\% over 2015. However, the development of this activity between 1990 and 2016 indicated a loss of almost $60 \%$ of the volume produced, from a level of approximately 20 thousand tons to 8 thousand tons/year (Conab 2017). Some factors corroborate for this; such as great loss during production peak due to high perishability (post-harvest life is only three days) associated with the absence of adequate crop and postharvest infrastructure, as well as small umbu commercial exploitation (Moura et al. 2013). However, the most recent data showed that 7,465 tons of umbu were produced in 2017 in Brazil, $74 \%$ (that is, 5,508 tons) in Bahia. The forecast for the 2018/2019 harvest was the highest of the last three years, in an amount that can reach 80 tons harvested between December / 2018 and April / 2019. This makes umbu, a symbol of Caatinga fruits, one of the top ten in the list of main food products from national plant extraction (PNUD
2019). This might make production cease to be interesting or render vulnerable the species natural environment.

In this sense, there is a need to adapt conventional technologies and develop new technologies for umbu processing to promote a more profitable and sustainable use. Industrialization adds economic value, minimizes production losses and meets the consumer market demands. Although umbu is already partially benefited on a small scale by cooperatives, it is not a properly characterized fruit yet, especially as regards to its potential for industrialization. In these processing units, in the period when a large production occurs, the fruits are cooked and hot-filled in hermetical recipients. This process guarantees long shelf life during storage at room temperature. Thus, products derived from umbu, as jellies and sweets, continue to be manufactured and marketed during off-season. However, research carried out in umbu processing units evidenced that there is no use of its residues, which are simply discarded (Batista et al. 2015). Literature studies were not found on residues from umbu processing.

Banerjee et al. (2017) points out that fruit industrialization generates a large amount of waste, about $20 \%$ to $50 \%$, consisting of peel, seeds and bagasse. In general, waste is destined for animal feed or fertilizer; however, most of it is still disposed of without treatment, causing potential problems of environmental pollution and economic loss, as they represent losses of raw material and energy. However, several studies have shown that fruit residues contain vitamins, minerals, fibers and antioxidant compounds in their composition and this content may be higher than that of the fruit edible portion (Jacometti et al. 2015, Leão et al. 2017, Sereno et al. 2018, Silva et al. 2014). 
Among the technologies used for agroindustrial waste utilization, dehydration to obtain flours shows some advantages, such as increase in shelf life and safety due to reduction of free water, facility to store at room temperature, reduction of volume and costs with transport and packaging and it is a relatively inexpensive process. Simultaneously, this process concentrates content of nutrients and bioactive compounds in the final product (Leão et al. 2017). Flour manufacturing process convenience and low cost can make possible to increase family incomes of those who survive from umbu extraction due to its greater added value and diversity of application. Flours can be used for nutritional supplementation, enrichment, preservation, and partial or total replacement of ingredients in food products, which depends on its chemical composition and technological properties (Martins et al. 2017). Flour from fruit residues can be commercially viable and emerge as an efficient strategy for food integral use, taking advantage of its nutritional properties, as well as waste reduction.

Taking into account the potential of fruit residues, the aim of this study was to obtain flour from residues generated by umbu processing and determine nutritional and mineral composition, fatty acid profile, antinutrients, bioactive compounds, antioxidant activity and technological properties, with the purpose to explore its potential use as a new functional ingredient in food products.

\section{MATERIALS AND METHODS}

\section{Flour preparation}

Umbu fruits (50 kg) were obtained in Campina Grande, Paraíba, Brazil and selected by skin color (partially dark green) and firm consistency pulp (half-ripe stage). The fruits were sanitized with $200 \mathrm{mg} / \mathrm{L}$ sodium hypochlorite for $15 \mathrm{~min}$ and boiled until presented skin cracks and brownish coloration (about 8-10 min). They were pulping through a sieve (10 mesh) and the residues (skin and seeds) were dried in a dryer with forced air circulation at $60 \pm 2^{\circ} \mathrm{C}$ until constant weight. Dried residues were ground in a knife mill (Marconi, model MA340) coupled with a 20mesh sieve. The flour obtained was hermetically packaged in placed in zipped bags (Royal Pack, Brazil) and stored at $25 \pm 2^{\circ} \mathrm{C}$. The Yield of the flour was calculated by dividing the final mass of product by the initial raw material and express as $\% \mathrm{w} / \mathrm{w}$. A sieve shaker (Produtest ${ }^{\oplus}$ ) was used to determine flour particle size, according to NBR 7217 (ABNT 1987). A 100 g-portion of flour was sieved for $15 \mathrm{~min}$, using a set of five round sieves, openings 10, 20, 30, 50 and 60-mesh. The contents retained in each sieve were weighed and expressed in retention percentages.

\section{Proximate, physicochemical analysis and mineral composition}

Moisture and fixed mineral residue were determined by gravimetric methods (AOAC 2005). Protein content was evaluated by Kjeldahl method, using a correction factor of 6.25 , and lipids were quantified by Soxhlet method with petroleum ether (AOAC 2005). Total, soluble and insoluble dietary fibers were determined by enzymatic gravimetric method (AOAC 2005). Energy value (kcal/100 g) was calculated by lipids, proteins and carbohydrates multiplied by 9, 4 and $4 \mathrm{kcal}$, respectively (Atwater \& Bryant 1990). Total and reducing sugars were determined by Lane and Eynon method (IAL 2008).

The $\mathrm{pH}$ was determined by potentiometer (MicroNAL, B474) in a homogenate, prepared with $5 \mathrm{~g}$ of flour and $50 \mathrm{~mL}$ of distilled water. Total titratable acidity was carried out by titration with 0.1 N NaOH, to pH 8.2-8.4 (IAL 2008). Water activity was directly measured using a 
water activity analyzer (Labtouch-aw, Novasina, Switzerland) at $25 \pm 3^{\circ} \mathrm{C}$.

The minerals potassium, calcium, phosphorus, sulfur, zinc and copper were analyzed by energy dispersive $X$-ray fluorescence (EDXRF), using X-ray fluorescence spectrometer (EDX-720, Shimatzu). Approximately $2 \mathrm{~g}$ of the sample were weighed in a specific sample port (31 mm Closed X-Cell - SPEX) using thin film of polypropylene (thin film for XRF, $5 \mu$-SPEX). The measurements were conducted in accordance with analytical conditions as follows: camera pressure less than $30 \mathrm{~Pa}, 15 \mathrm{kV}$ voltage for elements K, Ca, P, S, $50 \mathrm{kV}$ voltage for elements $\mathrm{Zn}$ and $\mathrm{Cu}, \mathrm{Al}$ filter for $\mathrm{K}, \mathrm{Ag}$ filter for $\mathrm{Zn}$, time $100 \mathrm{~s}$, except sulfur (300 s), collimator $10 \mathrm{~mm}$. The standards used were SRM 8415 (whole egg powder), SRM 1547 (peach leaves) and SRM 1573a (tomato leaves) obtained from Sigma-Aldrich. Magnesium and iron were determined by atomic absorption spectrophotometry by flame (FAAS) (Varian model GTA 110), using a calibration curve for each mineral. Analysis was carried out after nitric-perchloric acid digestion $(4: 1 \mathrm{v} / \mathrm{v})$ in microwave (Mars-5 CEM) at $150^{\circ} \mathrm{C}$ for $30 \mathrm{~min}$, and $75 \%$ of maximum power $(1600 \mathrm{~W})$. The results were expressed in $\mathrm{mg} / 100 \mathrm{~g}$.

\section{Fatty acids profile}

Lipid fraction (25 mg) was obtained by cold extraction using chloroform, methanol, and water (2:2:1.8, v/v/v) according to Bligh \& Dyer method (1959). The lipidic fraction obtained was transesterified to methyl esters, using potassium hydroxide in methanol and n-hexane, according to AOCS Ce 2-66 method (2009). The sample was stocked in amber glass bottle, inertized with nitrogen gas, and stored at $-18^{\circ} \mathrm{C}$ until the moment of analysis. Fatty acid methyl esters (FAMEs) obtained were analyzed, using a gas chromatograph (Agilent Technologies, 7890A), equipped with a flame-ionization detector (FID), injector split and automatic sampler. FAMEs were separated by using a DB-5ms column (30 $\mathrm{m}$ length $\times 250 \mu \mathrm{m}$ diameter $\times 0.25 \mu \mathrm{m})$. The column oven temperature was initially held at $150^{\circ} \mathrm{C}$ for $4 \mathrm{~min}$, heated at $4^{\circ} \mathrm{C} / \mathrm{min}$ until $280^{\circ} \mathrm{C}$ and maintained at $280^{\circ} \mathrm{C}$ for $5 \mathrm{~min}$. Injector and detector temperatures were $300^{\circ} \mathrm{C}$. Samples of $1.0 \mu \mathrm{L}$ were injected adopting a split ratio of 1:10. Carrier gas was helium with a flow rate of $1 \mathrm{~mL} / \mathrm{min}$. FAMEs were identified by comparing their retention times with those of pure FAME standards (FAME Supelco TM mix C4-C24, Bellefonte, PA, USA), under the same operating conditions. The results were expressed as percentages of individual fatty acids in the lipid fraction $(w / w)$.

\section{Phytochemical screening and anti-nutritional factors}

Tannins, flavones, flavonols, xanthones, anthraquinones, steroids, triterpenoids, depsides, depsidonas, saponins and alkaloids were qualitatively analyzed according to Matos (1997). Extracts of flour were prepared in triplicate as follows: $5 \mathrm{~g}$ of flour were sequentially extracted with $30 \mathrm{~mL}$ of acetone $(80 \% \mathrm{v} / \mathrm{v}), 30$ $\mathrm{mL}$ of ethyl alcohol $(80 \% \mathrm{v} / \mathrm{v})$ and $30 \mathrm{~mL}$ of methanol $(80 \% \mathrm{v} / \mathrm{v})$. Samples were stirred for 20 min at room temperature $\left(25^{\circ} \mathrm{C}\right)$ and centrifuged at 15,000 rpm for 15 min after each extraction cycle. Supernatants were combined and final volume was increased to $100 \mathrm{~mL}$ with distilled water. Extracts were stocked in amber bottles and stored at $4^{\circ} \mathrm{C}$. These analyzes consisted of observing color changes and /or precipitate formation in the extracts when specific reagents were used for each compound. Tannins were identified using 1\% (w/v) alcoholic ferric chloride solution. Flavones, Flavonoids and Xanthones were identified changing the $\mathrm{pH}$ of the extracts with $\mathrm{HCl}$ and $\mathrm{NaOH}$. To detect anthraquinones, toluene and 10\% ammonium hydroxide were 
used. Steroids and Triterpenoids were identified by adding chloroform and acetic anhydride to the extracts under agitation followed by the addition of sulfuric acid. Depsides and Depsidones were detected by adding ethyl ether to the extracts, followed by evaporation and addition of methanol and $1 \%$ (w/v) ferric chloride. Saponins were identified by foaming after vigorous stirring of the extracts and for alkaloids, lugol and hydrochloric acid were used.

For the quantification of nitrate, $0.1 \mathrm{~g}$ of the flour was dispersed in $10 \mathrm{~mL}$ of deionized water and submitted to a water bath at $45^{\circ} \mathrm{C}$. The mixture was centrifuged at 2,500 rpm for 30 min. $0.5 \mathrm{~g}$ of activated carbon was added, followed by manual stirring and resting for 10 min. The extract to be analyzed was obtained after filtration on quantitative paper with slow filtration and nitrate was quantified by salicylic acid method using sodium nitrate as standard (0-960 mg/ L) (Cataldo et al. 1975).

To determine the tannins, $0.2 \mathrm{~g}$ of the flour was homogenized with $10 \mathrm{~mL}$ of methanol on a magnetic stirrer for $20 \mathrm{~min}$, followed by centrifugation at 4,000 rpm for $20 \mathrm{~min}$. The supernatant was transferred to a $10 \mathrm{~mL}$ volumetric flask and the volume completed with methanol. The tannins contained in the extract were analyzed by Vanillin-HCl method using catechin as standard $(0-1000 \mu \mathrm{g} / \mathrm{mL}$ ) (Price et al. 1980).

Trypsin inhibitors were extracted with $\mathrm{NaOH} 0.1 \mathrm{~mol} / \mathrm{L}$ in magnetic stirring for $1 \mathrm{~h}$ in the ratio $1: 10(\mathrm{w} / \mathrm{v})$ at room temperature $\left(25^{\circ} \mathrm{C}\right)$. After centrifugation at 6,000 rpm for $5 \mathrm{~min}$, an aliquot of the supernatant was used in the enzyme activity assay using trypsin and BApNA substrate (benzoyl-DL-arginine-p-nitroanilide) (Kakade et al. 1974). For lectins analysis, the flour (1g) was suspended in $10 \mathrm{~mL}$ sodium chloride solution $0.85 \mathrm{~g} / 100 \mathrm{~mL}(\mathrm{pH}=7.4)$ and stirred for $3 \mathrm{~h}$ at room temperature $\left(25^{\circ} \mathrm{C}\right)$. The extract was then filtered and the hemagglutinating activity determined using microtiter plates, according to Calderon de la Barca et al. (1985).

\section{Bioactive compounds}

Total carotenoids were extracted and quantified according to Rodriguez-Amaya \& Kimura (2004). Briefly, samples of $2 \mathrm{~g}$ of flour were added to $40 \mathrm{~mL}$ of ice-cold acetone $\left(5^{\circ} \mathrm{C}\right)$ and homogenized manually; extraction was repeated thrice until the sample become colorless. After vacuum filtration, the extract was placed in a separating funnel containing $20 \mathrm{~mL}$ of distilled water and $30 \mathrm{~mL}$ of petroleum ether. After washing with distilled water, the extract was filtered on filter paper with anhydrous sodium sulfate and transferred to a $50 \mathrm{~mL}$ volumetric flask, making up the volume with petroleum ether. Total carotenoids were quantified by spectrophotometry at $450 \mathrm{~nm}$ and calculated considering an absorption coefficient of 2500 , expressed as $\mu \mathrm{g} / 100 \mathrm{~g}$ flour.

Ascorbic acid was determined by method described by Strohecker \& Henning (1967). Briefly, $5 \mathrm{~g}$ of flour were homogenized with 50 $\mathrm{mL}$ of oxalic acid ( $1 \% \mathrm{w} / \mathrm{v}$ ) followed by filtering; an aliquot of $10 \mathrm{~mL}$ of this filtered was diluted in $50 \mathrm{~mL}$ of oxalic acid ( $1 \% \mathrm{w} / \mathrm{v})$, and $5 \mathrm{~mL}$ of this extract was titrated using 2,6-dichlorophenol indophenol and compared to the ascorbic acid standard titration $(50 \mu \mathrm{g} / \mathrm{mL})$. The results were expressed as mg ascorbic acid/100 g flour.

In order to determine the phenolics and flavonoids, the flour extracts were obtained in triplicate as described in item 2.4 for the phytochemical screening. To determine the phenolics, the extract $(20 \mu \mathrm{L})$ was homogenizing with $100 \mu \mathrm{L}$ of Folin-Ciacouteu reagent (1:10). After $3 \mathrm{~min}, 100 \mu \mathrm{L}$ of $7.5 \%$ (w/v) calcium carbonate was added. After $2 \mathrm{~h}$ of reaction at room temperature $\left(25^{\circ} \mathrm{C}\right)$, a spectrophotometer reading was performed at $735 \mathrm{~nm}$ (Singleton \& 
Rossi, 1965). Gallic acid (100-1000 $\mu \mathrm{g} / \mathrm{mL})$ was used as standard, and the results were expressed as mg gallic acid equivalent (GAE)/100 g flour.

Total flavonoid content was estimated in the extract by $\mathrm{AlCl}_{3}$ method (Lamaison \& Carnet 1990). Each extract $(100 \mu \mathrm{L})$ was added to equal volumes of a solution of $2 \%(\mathrm{w} / \mathrm{v}) \mathrm{AlCl}_{3}$ in methanol. The mixture was vigorously shaken, and absorbance was read at $420 \mathrm{~nm}$ after $1 \mathrm{~h}$ of incubation. The results were expressed as $\mathrm{mg}$ quercetin equivalent (QE)/100 g flour through the calibration curve of quercetin $(10-60 \mu \mathrm{g} / \mathrm{mL})$.

\section{In vitro antioxidant activity}

In vitro antioxidant activity of the extracts was evaluated by DPPH, ABTS and FRAP assays. DPPH radical scavenging activity was analyzed according to Brand-Williams et al. (1995) using the stable radical DPPH (1.1-diphenyl-2picrylhydrazyl), with adaptations for microplate analysis. Briefly, an aliquot of $40 \mu \mathrm{L}$ of extract in different concentrations (3.125, 6.25 and $12.5 \mathrm{mg}$ / $\mathrm{mL}$ ) was added into wells of microplate followed by $250 \mu \mathrm{L}$ of DPPH methanolic solution (0.1 mM). The mixture was incubated at room temperature $\left(25^{\circ} \mathrm{C}\right)$ for $25 \mathrm{~min}$ in the dark. Absorbance was measured at $517 \mathrm{~nm}$, using a control solution (0.1 mM DPPH) and a blank (methanol). Percentage of DPPH radical scavenging activity was calculated using equation 1: $\left\{\left[\left(\mathrm{Abs}_{\text {control }}-\mathrm{Abs}_{\text {sample }}\right) / \mathrm{Abs}_{\text {control }}\right]\right.$ $\times 100\}$. The amount of antioxidant required to decrease the initial concentration of DPPH by $50 \%\left(I C_{50}\right)$ in a fixed reaction time was determined by linear regression.

ABTS radical scavenging activity was measured according to Re et al. (1999) in different concentrations of extract $(3.125,6.25$ and $12.5 \mathrm{mg} / \mathrm{mL}$ ). The 2,2'-azino-bis (3, ethyl benz-thiazoline-6-sulfonic acid) radical cation $\left(\right.$ ABTS $^{+}$) was obtained by reaction of $5 \mathrm{~mL}$ of $7 \mathrm{mM}$ ABTS solution with $88 \mu \mathrm{L}$ of $140 \mathrm{mM}$ potassium persulphate. The mixture was kept in the dark for $16 \mathrm{~h}$ before use and then diluted with ethanol to obtain an absorbance of $0.7 \pm$ 0.05 at $734 \mathrm{~nm}$. The samples $(30 \mu \mathrm{L})$ were mixed with $3 \mathrm{~mL}$ of the ABTS radical solution and the absorbance at $734 \mathrm{~nm}$ was measured after 6 min in the dark. Percentage of ABTS radical inhibition was calculated using equation 1, previously described. Trolox was used as standard (250$2000 \mu \mathrm{M})$ and trolox equivalent antioxidant capacity (TEAC) was expressed as $\mu \mathrm{M}$ trolox/g flour.

Ferric reducing antioxidant power (FRAP) assay was carried out according to Benzie \& Strain (1999) in different concentrations of extract $(3.125,6.25$ and $12.5 \mathrm{mg} / \mathrm{mL})$. FRAP reagent $(180 \mu \mathrm{L})$ was mixed with the extracts $(20 \mu \mathrm{L})$, incubated at $37^{\circ} \mathrm{C}$ for $30 \mathrm{~min}$ and the absorbance determined at $593 \mathrm{~nm}$. It was prepared by mixing $10 \mathrm{mM}$ 2,4,6-tris (1-pyridyl)-5-triazine in $40 \mathrm{mM}$ $\mathrm{HCl}$ with a $20 \mathrm{mM} \mathrm{FeCl}_{3}$ solution and $0.3 \mathrm{M}$ acetate buffer $(\mathrm{pH}$ 3.6) in the proportion 1:1:10 ( $/ \mathrm{v} / \mathrm{v} / \mathrm{v})$. Ferrous sulfate was used as standard (250-2000 $\mu \mathrm{M})$. The results were expressed as $\mu \mathrm{M}$ ferrous sulfate /g flour.

\section{Technological properties}

Water absorption capacity (WAC) was determined according to Sosulski (1962). Oil absorption capacity (OAC) was determined according to Lin et al. (1974) and emulsifying capacity (EC) and emulsion stability (ES) were determined according to Dench et al. (1981), using soybean oil.

\section{Statistical analysis}

All the experiments were carried out in triplicate. The values of different parameters were expressed as mean \pm SD (standard deviation). The correlation between antioxidant capacity and phenolic compounds were determined using Pearson's Correlation Coefficient Test. Significance levels were set at $p<0.05$. 


\section{RESULTS AND DISCUSSION}

\section{Flour yield and particle size}

Flour yield was $13.14 \%$. This value is equivalent to umbu fruit percentage of seeds related by Costa et al. (2015). To extract the umbu pulp in the industry, especially with half-ripe fruits, peel and pulp are homogenized together, not having influence of peel thickness on the industrial yield, in quantitative terms (Batista et al. 2015). So, considering the large amount of fruit in umbu harvest period, residue exploitation, a renewable, abundant and low-cost resource, could be carried out by cooperatives which process umbu, with opportunities of added value to the fruit, developing new products as well as reducing industrial waste.

Most flour particles (80\%) were retained on sieves sized 50 mesh $(0.30 \mathrm{~mm})$, classified as fine according to Zanotto \& Bellaver (1996). Particle size affects water absorption capacity and mixing time as well as sensory characteristics such as appearance, taste and texture, when incorporated into food formulations. The results found here indicate that this product has potential to be used in bakery products, because of fine and uniform particles promote greater flour dispersibility in dough (Bressiani et al. 2017).

\section{Physicochemical analysis}

Table I shows the results for proximate composition and physicochemical characteristics of the flour. Moisture content obtained $(7.64 \pm 0.01)$ is in accordance with current Brazilian legislation for edible vegetable flours, which stipulate a maximum of $15 \%$ (Anvisa 2005). Moisture low values, water activity, and $\mathrm{pH}$ associated to high acidity indicate low susceptibility to the growth of microorganism (Beuchat et al. 2013, Rousk et al. 2009). These intrinsic characteristics can confer stability and
Table I. Physicochemical composition of umbu (Spondias tuberosa Arr. Cam.) processing waste flour.

\begin{tabular}{|c|c|}
\hline Components & Values \\
\hline Moisture (\%) & $7.64 \pm 0.01$ \\
\hline Ash (\%) & $2.63 \pm 0.09$ \\
\hline Lipids (\%) & $7.53 \pm 1.06$ \\
\hline Palmitic acid (C16:0) (\%) & $24.18 \pm 0.19$ \\
\hline Stearic acid (C18:0) (\%) & $13.07 \pm 0.04$ \\
\hline Oleic acid (c18:1n-9) (\%) & $33.31 \pm 0.13$ \\
\hline Linoleic acid (c18:2n-6) (\%) & $29.44 \pm 0.04$ \\
\hline Proteins (\%) & $5.60 \pm 0.12$ \\
\hline Carbohydrate (\%) & $15.39 \pm 0.94$ \\
\hline Total sugars (\%) & $11.79 \pm 0.75$ \\
\hline Reducing sugars (\% glucose) & $9.99 \pm 0.72$ \\
\hline Total Dietary Fiber (\%) & $61.21 \pm 0.47$ \\
\hline Insoluble Dietary Fiber (\%) & $56.67 \pm 0.29$ \\
\hline Soluble Dietary Fiber (\%) & $4.54 \pm 0.18$ \\
\hline Energy (kcal/100 g) & $151.75 \pm 5.55$ \\
\hline Titratable total acidity (\% citric acid) & $4.96 \pm 0.05$ \\
\hline $\mathrm{pH}$ & $3.19 \pm 0.38$ \\
\hline Water activity at $25.7 \pm 0.3^{\circ} \mathrm{C}$ & $0.51 \pm 0.00$ \\
\hline
\end{tabular}

Data represent the mean of triplicate determinations \pm standard deviation.

safety at room temperature storage and prolong product shelf life. Similar results were observed in acerola flour, which presented high quality and physicochemical stability during 75 days of storage at room temperature (Reis et al. 2017). These results show that residue processing as flour allows less demanding storage conditions, allowing cooperatives with fewer infrastructures to be suitable for this processing.

Ash refers to total mineral content of a food and is affected by several factors, such as cultivar, soil, weather, agricultural practices and ripeness stage (Almeida et al. 2009). Mineral analysis (Fig. 1a-b) showed considerable amounts of macrominerals: potassium (924.2 $\pm 132.0 \mathrm{mg} / 100$ 

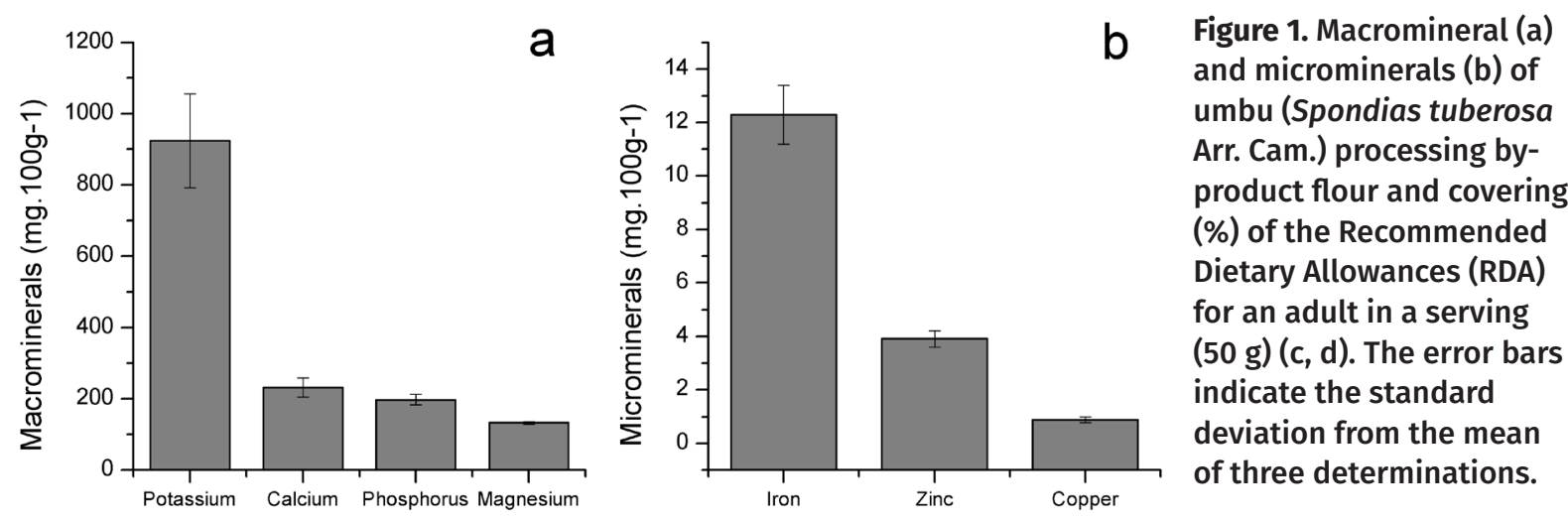

C
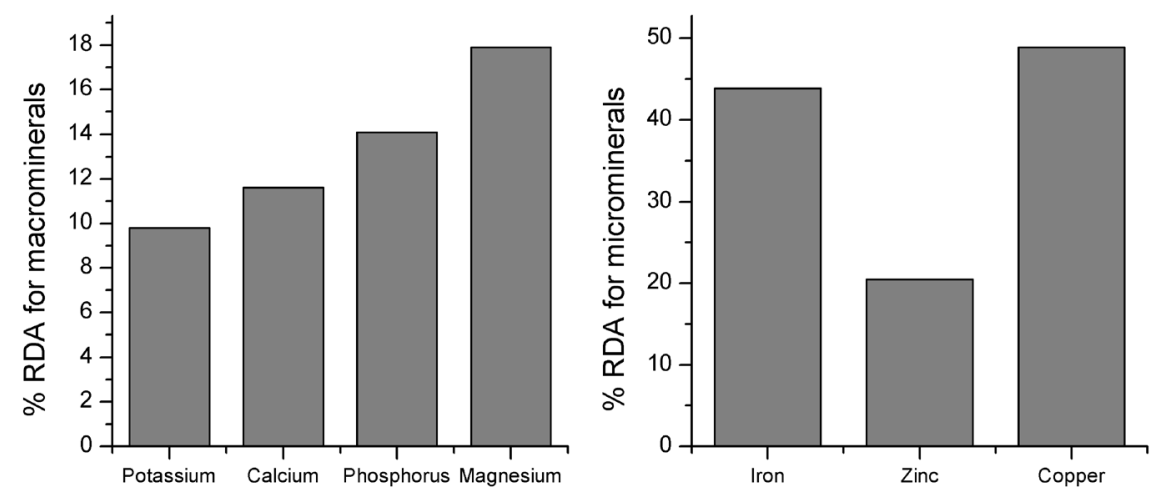

g), calcium (231.7 $\pm 26.7 \mathrm{mg} / 100 \mathrm{~g})$, phosphorus (197.1 $\pm 15.1 \mathrm{mg} / 100 \mathrm{~g})$ and magnesium (132.6 \pm $4.2 \mathrm{mg} / 100 \mathrm{~g})$, as well as microminerals: iron $(12.3 \pm 1.1 \mathrm{mg} / 100 \mathrm{~g})$, zinc $(3.9 \pm 0.3 \mathrm{mg} / 100 \mathrm{~g})$ and copper $(0.88 \pm 0.1 \mathrm{mg} / 100 \mathrm{~g})$ in the flour. As compared to umbu fresh pulp evaluated by Almeida et al. (2009), the flour presented values up to $22 \%$ higher values in minerals analyzed. Data in literature corroborate that fruit byproducts present higher values of minerals than the edible part (Gondim et al. 2005, Inada et al. 2015). In addition, process of dehydration to obtain the flour concentrates the minerals, which increases their amounts per serving.

Minerals are usually divided in macrominerals and microminerals with organic requirements $>100 \mathrm{mg} /$ day and $<100 \mathrm{mg} /$ day, respectively (Padovani et al. 2006). The results obtained in relation to a flour serving (50 g) ranged from $9.8 \%$ to $17.9 \%$ for macrominerals and $20.5 \%$ to $48.9 \%$ for microminerals (Fig. 1 c-d), regarding percentage contributions for minerals by Recommended Dietary Allowances (RDA). Foods are considered "excellent" or "good" nutrient sources when a serving can supply at least 20 or $10-20 \%$ of the RDA, respectively (FDA 1993). Thus, the flour obtained can be classified as a good dietary source of calcium, phosphorus and magnesium and an excellent source of iron, zinc and copper.

Iron, for example, is an important micronutrient that, in Brazil, has been largely used in food fortification programs for anaemia prevention, because one of the strategies used to prevent iron-deficiency is increased dietary iron intake (Wong 2017). Considering that a flour serving (50 g) contributes with $43.9 \%$ of RDA for iron, certainly might be a low-cost alternative to 
supplement daily of iron intake, by applying in food fortification, especially socially vulnerable populations.

Total lipid content found in the flour (Table I) can be considered economically attractive for industrial extraction, especially when compared with other raw materials, as corn, which have lipid content of 3.1-5.7\% (White \& Johnson 2003). Studies have shown that, depending on total lipid content and fatty acid composition, agroindustrial residues present great potential for extraction of good quality oil, which is rich in bioactive compounds (phytosterols, tocopherols, carotenoids), with good yield for food and pharmaceutical industry and even for biofuel production (Luzia \& Jorge 2013). Oils extracted from agro-industrial wastes have showed similar physicochemical characteristics to conventional edible oils (soybean, sunflower, corn), so they can be used as a source of oil extraction for use in food preparations (Chivandi et al. 2016).

In general, seeds are rich in unsaturated fatty acids, particularly oleic and linoleic (Lachman et al. 2015, Pereira et al. 2017). Palmitic, stearic, oleic and linoleic fatty acids were detected in flour lipid fraction. The results showed a higher proportion of unsaturated fatty acids (62.75\%), being oleic about $12 \%$ higher than linoleic acid (Table I). In relation to saturated fatty acids, palmitic acid was predominant, followed by stearic acid. Similar results were reported by Borges et al. (2007) in umbu seeds from two different varieties in the unripe and ripe stages, obtained in Petrolina, Pernambuco, Brazil. However, they also found arachidic acid in low values. This difference can be attributed to temperature, humidity, soil nature and other climatic factors prevailing in cultivation locality (Younis et al. 2000).

Linoleic acid (cis-9,12-Octadecadienoic acid, C18:2n-6) is a polyunsaturated fatty acid (PUFA) namely "essential fatty acid", because it cannot be synthesized by human body and must be supplied exclusively by diet (Dorni et al. 2018). Like this, intake of flour serving (50 g) contributes with $7.58 \%$ of RDA linolenic acid. Another advantage of the flour is polyunsaturated (PUFA) and saturated fatty acid (SFA) ratio, of 0.79 ; this parameter shows that flour lipid fraction no confer risk for cardiovascular diseases, being considered beneficial to health. Diets presenting ratio $<0.45$ are considered undesirable, because they may lead to increased blood cholesterol levels (Department of Health and Social Security 1984).

In relation to technological application, fatty acid composition of an oil or fat is important because it is related to oxidative stability, and it makes possible to define the main application, in terms of nutrition and culinary, as well as the effects on human health. In general, high degree of fatty acid unsaturation makes it highly susceptible to oxidative deterioration at high temperatures (Brinkmann 2000). Vegetable oils with high quantity of oleic acid are more appropriate in frying processes due to highest stability during heating and for use in industrialized foods, which require longer shelf life and increase palatability, such as snacks, crackers, cereals, dried fruit and bakery products (Luzia \& Jorge 2013).

Oleic acid percentage presented in flour lipid fraction was higher than common edible oils used in culinary and food products, such as soybean $(21.35 \%)$, corn $(24.23 \%)$, sunflower (15.26\%) and cottonseed oils (16.61\%) (Zambiazi et al. 2007). This data is interesting because extend the applications of this raw material. Considering that industries of edible oils have been concentrated in vegetable oils with high content of oleic acid, flour can be a new source of good quality and low-cost oil, when compared to other raw-materials. It may be used 
as edible cooking or salad oils or for margarine manufacture.

The flour presented high content of sugars and dietary fiber and low energy value (Table I). According to Anvisa (2012), this flour can be considered as good source of total sugars and with high content dietary fiber, since it provides about $5.8 \mathrm{~g}$ and $30.6 \mathrm{~g}$, respectively, in a serving (50 g). Approximately 20 to $30 \mathrm{~g}$ of the flour (2 to 3 tablespoons) is sufficient for supplying half the dietary fiber recommended intake (Padovani et al. 2006). This result indicates that the flour can be a functional ingredient due to beneficial effects of fibers on human health. It is relatively difficult for most people to meet daily fiber intake requirements; one way to increase their intake is to enrich foods with high-fiber ingredients such as cakes, cookies and other products. Additionally, these foods could be considered as foods with functional claims of promote reduce the absorption of cholesterol and sugar, weight reduction, regulate digestion, prevent constipation, and improve the balance of the intestinal microflora (Dai \& Chau 2017).

\section{Phytochemical screening and anti-nutritional factors}

The results of phytochemical screening of the flour indicated the presence of tannins, flavones, flavonols, xanthones, depsides and depsidones. Presence of these compounds arouses the interest for investigations on possible biological activities of the flour, such as antimicrobial, anti-inflammatory and antioxidant activities (Ksouri et al. 2013). Anthraquinones, steroids, triterpenoids, saponins and alkaloids were not detected. According to Clerici et al. (2011), the absence of alkaloids ensures safe use of this product as food ingredient.

Nitrates are naturally present in the environment and in plants, since the plant uses them as a source of nitrogen for their growth.
Studies have indicated that the consumption may be harmful to human health, causing methahemoglobinaemia and gastric cancer (Campanella et al. 2017). The flour presented low value of nitrate (Table II). An Acceptable Daily Intake (ADI) of 0-3.7 mg/ kg body weight, equivalent to $222 \mathrm{mg}$ nitrate per day for a 60 $\mathrm{kg}$ adult (EFSA 2008). Thus, the intake of a flour serving (50 g) does not pose risk to health, because it contributes with only $6.96 \mathrm{mg}$.

Tannins are water-soluble polyphenolic compounds linked to negative effects on nutritional properties as a result of the ability to complex and precipitate proteins in aqueous solutions, reducing protein and amino acid digestibility, as well as polysaccharides and minerals (Schofield et al. 2001). In foods, tannins may affect food color due to enzymatic browning reactions and decrease its palatability due to astringency (Medel-Maraboli et al. 2017). Tannin content of flour (Table II) was lower than the values reported for cereals and grain legumes, up to $7200 \mathrm{mg} / 100 \mathrm{~g}$, by Gilani et al. (2012). This low value would not imply deleterious effects on protein digestibility and mineral bioavailability.

Another excellent result was absence of trypsin inhibitors and lectins in flour. Protease inhibitors cause pancreatic hypertrophy/ hyperplasia and lectins' ability to bind glycoprotein receptors to epithelial cells, lining intestinal mucosa; inhibits growth by interfering with the absorption of nutrients (Mohan et al. 2016). These factors are thermosensitive and may have been inactivated during thermal processing to which umbu fruits were submitted to obtain flour.

\section{Bioactive compounds}

Ascorbic acid is an essential water-soluble vitamin with great reducing properties and high antioxidant activity due to free radical neutralization and other reactive oxygen 
Table II. Anti-nutritional factors, bioactive compounds and antioxidant activity of umbu (Spondias tuberosa Arr. Cam.) processing waste flour.

\begin{tabular}{|c|c|c|c|c|c|}
\hline \multicolumn{2}{|c|}{ Anti-nutritional factors } & \multicolumn{2}{|c|}{ Bioactive compounds } & \multicolumn{2}{|c|}{ Antioxidant activity } \\
\hline $\begin{array}{c}\text { Nitrate } \\
(\mathrm{mg} / 100 \mathrm{~g})\end{array}$ & $13.93 \pm 0.17$ & $\begin{array}{l}\text { Ascorbic acid } \\
\text { (mg AA/100 g) }\end{array}$ & $44.78 \pm 5.55$ & $\begin{array}{c}\text { DPPH } \\
\text { (\% inhibition) }\end{array}$ & $96.92 \pm 0.67$ \\
\hline $\begin{array}{l}\text { Tannins } \\
\text { (mg/100 g) }\end{array}$ & $88.52 \pm 0.33$ & $\begin{array}{l}\text { Carotenoids } \\
(\mu \mathrm{g} / 100 \mathrm{~g})\end{array}$ & $463.73 \pm 35.80$ & $\begin{array}{c}\text { ABTS } \\
\text { (\% inhibition) }\end{array}$ & $99.66 \pm 0.03$ \\
\hline $\begin{array}{l}\text { Trypsin inhibitors } \\
\text { (mg TI/g) }\end{array}$ & n.d. & $\begin{array}{l}\text { Total phenolics } \\
\text { (mg GAE/100 g) }\end{array}$ & $20357.26 \pm 1287.19$ & $\begin{array}{c}\text { TEAC } \\
(\mu \mathrm{M} \text { trolox/g) }\end{array}$ & $42.45 \pm 0.02$ \\
\hline $\begin{array}{l}\text { Lectin } \\
(\mathrm{HU} / \mathrm{ml})\end{array}$ & n.d. & $\begin{array}{l}\text { Flavonoids } \\
\text { (mg QE/100 g) }\end{array}$ & $37.85 \pm 0.48$ & $\begin{array}{c}\text { FRAP } \\
(\mu \mathrm{M} \text { ferrous sulfate } / \mathrm{g})\end{array}$ & $137.77 \pm 8.44$ \\
\hline
\end{tabular}

Data represent the mean of triplicate determinations \pm standard deviation. $\mathrm{TI}=$ Trypsin inhibitors. HU = Hemagglutinating units. GAE = Gallic acid equivalent. $Q E=$ Quercetin equivalent. $A A=$ Ascorbic acid. TEAC = Trolox equivalent antioxidant capacity. n.d.: Not detected. Data represent the mean of triplicate determinations \pm standard deviation.

species. It is considered as the nutrient quality indicator during processing and storage due to its susceptibility to rapid degradation (Skrovankova et al. 2015). Fruits can be classified according to ascorbic acid content in three categories: low (<30 mg/100 g), medium (30 - 50 $\mathrm{mg} / 100 \mathrm{~g}$ ) and high (>50 mg/100 g) (Ramful et al. 2011). According to this classification the umbu flour included in medium category (Table II). Unlike what was observed in this work, Melo \& Andrade (2010) found a high content of ascorbic acid when evaluated half-ripe umbu dried peels (144.91 mg / $100 \mathrm{~g}$ ). This fact could be attributed probably to the type of by-product used, since those authors used only skin and the flour was obtained from the skin and seed, as well as still the probable degradation of ascorbic acid during umbu fruit cooking in the process of obtaining flour. However, the value obtained in this work is higher than the content of ascorbic acid reported in umbu pulp (12.1 mg/100 g) by Almeida et al. (2011).

Carotenoids are pigments mostly responsible for orange, yellow or red color of vegetables and are important vitamin A precursors. Studies indicate that carotenoids may prevent cardiovascular diseases due to its strong antioxidant activity based on quenching singlet oxygen $\left({ }^{1} \mathrm{O}_{2}\right)$ and free radical scavenging (Kulczyński et al. 2017). Humans are not capable of synthesizing carotenoids; thus, they have to be supplied by diet. The flour presented carotenoid content (Table II) similar to papaya by-product (490.29 $\mu \mathrm{g} / 100 \mathrm{~g}$ dry basis) and higher than other tropical fruits by-products, such as pineapple, acerola, cashew fruit, guava, mango and passion fruit (Silva et al. 2014).

Phenolic compounds are a large class of secondary plant metabolites that play a fundamental role defend environmental stresses, and are important constituents of human diet due to its antioxidant power. The high value of total phenolic compounds obtained in flour (Table II), is much higher than the displays found in the literature for other fruit by-products like for example kinnow seed and peel, Litchi pericarp, Grape seed and Banana peel (Babbar et al. 2011); seeds from 11 fruits (Chen et al. 2016) and of by-products samples containing different sessions of 12 tropical from brazil fruit (Silva et al. 2014). This result shows that antioxidant compounds should be located mainly in umbu seeds, because umbu half-ripe dried peels showed lower values (466.17 mg 
GAE/100 g) (Melo \& Andrade 2010). Therefore, the flour can be considered an excellent source of phenolic compounds. Flavonoid content was higher than other Brazilian exotic fruit residues, as achachairu (2.15 mg QE/100 g), araçá-boi (2.52 mg QE/100 g) and bacaba (10.25 mg QE/100 g) (Barros et al. 2017). This finding provides potential applications of the flour as source for nutraceutical supplements, dietary additives and/or pharmaceutical products.

Bioactive compounds production is the result of secondary metabolism of plants and depends on genetic and, mainly, environmental factors. The greater the exposure of the plant to adverse conditions, such as high sun incidence, water stress and soil poor in nutrients, the greater the production of these compounds (Mohan et al. 2016). This may explain the very high levels of phenolic compounds found in the flour, since "umbuzeiro" is considered an icon tree by rural communities of Caatinga biome, a Brazilian northeast semi-arid area, because trees blossom and bear fruits during dry season, evidencing its high resistance even with low rainfall or irrigation (Neto et al. 2010).

\section{Antioxidant activity}

It is known that foods rich in antioxidants play an essential role in the prevention of diseases. The antioxidant capacity of fruits varies according to the contents of ascorbic acid, flavonoids, anthocyanins, and other phenolic compounds. In this work the flour showed a high antioxidant activity for all methods assayed (Table II), similar values to that obtained in dried peels of half-ripe and ripe umbu (Melo \& Andrade 2010). According to Hassimotto et al. (2005), percentages of DPPH and ABTS inhibition were considered high, because they were above $70 \%$ inhibition. Low value $(3.68 \pm 1.71 \mathrm{mg} / \mathrm{mL})$ of $\mathrm{IC}_{50}$ indicates a greater ability to neutralize free radicals. TEAC value and FRAP assay showed good free radical scavenging ability when compared with other fruit by-products (Babbar et al. 2011, Chen et al. 2016, Deng et al. 2012).

Phenolic compound content showed strong linear correlations with DPPH $(r=0.74)$, ABTS $(r=$ $0.99)$ and FRAP ( $r=0.92)$ assays. Literature data reported the same type of linear correlation between antioxidant activities and phenolic contents in fruits (Almeida et al. 2011, Gregoris et al. 2013). The results show phenolic compounds as one of the main components responsible for antioxidant activity in flour and ABTS was the most sensitive assay in measuring antioxidant activity of flour, followed by FRAP and DPPH. However, other antioxidant compounds, such as carotenoids and ascorbic acid, can contribute through synergic and antagonist effects to antioxidant potential, even in low concentrations (Rufino et al. 2010).

Antioxidant activity results indicate that flour is a promising material for the extraction of bioactive compounds, with the possibility of application in food, as a natural antioxidant, contributing to avoid oxidative reactions that occur in food systems, especially meat and fish products, during storage, allowing preservation and increase of quality (Kowalska et al. 2017). Furthermore, food, rich in bioactive compounds and high antioxidant activity can contribute to health-promoting and disease-preventing (Skrovankova et al. 2015).

\section{Technological properties}

Success in the application of fruit residue flours in food products depends on technological properties they present. These properties are defined as intrinsic physicochemical characteristics of the components, generally related to interaction with water and oil, and can be used to predict technological impact of a particular ingredient on a food product (Martins et al. 2017). The result of the water absorption 
capacity of the flour presented high value of $783.33 \pm 28.87 \%$; result this can be directly related to high dietary fiber content. Fibers have high capacity of hydration and water holding because of the abundance of hydrophilic groups in chemical structure, especially soluble fiber (Cui et al. 2011). Thus, flour finds useful applications as functional ingredients to enhance viscosity and softness in foods, reduce the cost, prevent water syneresis, extend shelf life, and replace fat in bakery products, sauces, soups (creams), desserts and dairy (Elleuch et al. 2011).

Oil absorption capacity in flour was 255.28 $\pm 5.65 \%$, slightly higher value than mango seed flour (India cultivar) (215\%) and melon peel flour (226\%) (Mallek-Ayadi et al. 2017, Okpala \& Gibson-Umeh 2013). This property is due to the presence of hydrophobic groups, which can bind to oil, as non-polar amino acid side chains (Chandra et al. 2015). Flour ability to absorb oil is important in food because it favors flavor retention and improves palatability, yield and shelf-life extension. High value presented makes this flour appropriate for ingredient of food with a high percentage of fat and emulsions, particularly in bakery or meat products (Karaman et al. 2017). Moreover, the high value of oil absorption capacity in flour could be exploited as a functional ingredient to fat replacer in meat products, such as hamburgers, with the advantage of adding considerable amounts of antioxidants in relation to cereals fiber (Selani et al. 2016).

Regarding to emulsifying capacity and emulsion stability, flour presented values of 54.17 $\pm 3.61 \%$ and $49.59 \pm 2.36 \%$, respectively. Emulsifying capacity is related to surface properties, ability of a substance to act as an agent which facilitates solubilization or dispersion of two immiscible liquids. These properties are related to proteins, since high content carbohydrate and fiber can reduce emulsion capacity
(Jacometti et al. 2015). Emulsifying properties are technological functional properties, important in food formulations, such as comminuted meat products, mayonnaise, sauces, soups, cream cheese, and others.

\section{CONCLUSIONS}

Umbu processing waste flour can be considered a new ingredient of interest to food industry due to its high nutritional content, especially dietary fibers and minerals, absence of potentially toxic substances, high phenolic compounds content, stronger antioxidant activity and great technological properties, which can be exploited in meat, bakery and dairy products. Furthermore, incorporation into food products can confer reducing caloric value by replacement of fat in elaboration of new food products, with functional appeal. Still, the flour also could be used for production of functional ingredients and dietary supplements by pharmaceutical industries.

\section{Acknowledgments}

GSF thanks to Fundação de Amparo a Ciência e Tecnologia do Estado de Pernambuco (FACEPE) for his Master's scholarship. MGCC and MTSC express your gratitude to the Conselho Nacional de Desenvolvimento Científico e Tecnológico (CNPq) for research grants and fellowship. MPS thanks CNPq, grant number 423993/2018-6, for supported. The authors acknowledge CNPq and FACEPE for financial support. The authors declare no conflict of interest.

\section{REFERENCES}

ABNT - ASSOCIAÇÃO BRASILEIRA DE NORMAS TÉCNICAS. 1987. NBR 7217: Agregados - Determinação da composição granulométrica - Método de ensaio. Rio de Janeiro 1987.

ALMEIDA MMB, SOUSA PHM, FONSECA ML, MAGALHAES CEC, LOPES MDFG \& LEMOS TLG. 2009. Avaliação de macro e microminerais em frutas tropicais cultivadas no nordeste brasileiro. Ciênc Tecnol Aliment 29: 581-586. 
ALMEIDA MMB, SOUSA PHM, ARRIAGA AMC, PRADO GM, MAGALHÃES CEC, MAIA GA \& LEMOS TLG. 2011. Bioactive compounds and antioxidant activity of fresh exotic fruits from northeastern Brazil Food Res Int 44: 2155-2159.

ANVISA - AGÊNCIA NACIONAL DE VIGILÂNCIA SANITÁRIA. 2005. Resolução RDC no 263, de 22 de setembro de 2005. Regulamento técnico para produtos de cereais, amidos, farinhas e farelos. Retrieved July 30, 2017 from: http:// portal.anvisa.gov.br/legislacao\#/visualizar/27619.

ANVISA - AGÊNCIA NACIONAL DE VIGILÂNCIA SANITÁRIA. 2012. Resolução RDC no 54, de 12 de novembro de 2012. Regulamento Técnico sobre Informação Nutricional Complementar. Retrieved July 30, 2017 from: http://portal.anvisa.gov.br/documents /\%20 $33880 / 2568070 /$ rdc0054_12_11_2012.pdf/ c5ac23fd-974e-4f2c-9fbc-48f7e0a31864.

AOAC. 2005. Official Methods of Analysis, $18^{\text {th }}$ ed., Washington, DC: Association of Official Analytical Chemists.

AOCS. 2009. Official Methods and Recommended Practices of the American Oil Chemists Society, $16^{\text {th }}$ ed., Champaign: American Oil Chemists Society.

ATWATER WO \& BRYANT AP. 1900. In: $12^{\text {th }}$ Annual Report (1899) of the Storrs, Conectilcult Agricultural Experimental Station, University of Connecticut, Storrs: Conenecticut, p. $73-110$.

BABBAR N, OBEROI HS, UPPAL DS \& PATIL RT. 2011. Total phenolic content and antioxidant capacity of extracts obtained from six important fruit residues. Food Res Int 44: 391-396.

BANERJEE J, SINGH R, VIJAYARAGHAVAN R, MACFARLANE D, PATTI AF \& ARORA A. 2017. Bioactives from fruit processing wastes: Green approaches to valuable chemicals. Food Chem 225: 10-22.

BARROS RGC, ANDRADE JKS, DENADAI, M, NUNES ML \& NARAIN N. 2017. Evaluation of bioactive compounds potential and antioxidant activity in some Brazilian exotic fruit residues. Food Res Int 102: 84-92.

BATISTA FRC, SILVA SM, SANTANA, MFS \& CAVALCANTE AR. 2015. O umbuzeiro e o semiárido brasileiro. Campina Grande: INSA. 72 p.

BENZIE IF \& STRAIN JJ. 1999. Ferric reducing/antioxidant power assay: Direct measure of total antioxidant activity of biological fluids and modified version for simultaneous measurement of total antioxidant power and ascorbic acid concentration. Methods Enzymol 299: $15-27$.
BEUCHAT LR, KOMITOPOULOU E, BECKERS H, BETTS RP, BOURDICHON F, FANNING S, JOOSTEN HM \& TER KUILE BB. 2013. Low-water activity foods: increased concern as vehicles of foodborne pathogens. J Food Prot 76: 150-172.

BLIGH EG \& DYER WJ. 1959. A rapid method of total lipid extraction and purification. Can J Biochem Physiol 37: 911-917.

BORGES SV, MAIA MCA, GOMES RDCM \& CAVALCANTI NB. 2007. Chemical composition of umbu (Spondias tuberosa Arr. Cam) seeds. Quím Nova 30: 49-52.

BRAND-WILLIAMS W, CUVELIER ME \& BERSET CLWT. 1995. Use of a free radical method to evaluate antioxidant activity. LWT-Food Sci Technol 28: 25-30.

BRESSIANI J, ORO T, SANTETTI GS, ALMEIDA JL, BERTOLIN TE, GÓMEZ M \& GUTKOSKI LC. 2017. Properties of whole grain wheat flour and performance in bakery products as a function of particle size. J Cereal Sci 75: 269-277.

BRINKMANN B. 2000. Quality criteria of industrial frying oils and fats. Eur J Lipid Sci Tech 102: 539-541.

CALDERON DE LA BARCA AM, OCHOA JL \& VALENCIA ME. 1985. Effect of the extraction of a hemagglutinin on the nutritive value of Amaranthus leucocarpus seeds. I Food Sci 50: 1700-1702.

CAMPANELLA B, ONOR M \& PAGLIANO, E. 2017. Rapid determination of nitrate in vegetables by gas chromatography mass spectrometry. Anal Chim Acta 980: 33-40.

CATALDO DA, MAROON M, SCHRADER LE \& YOUNGS VL. 1975. Rapid colorimetric determination of nitrate in plant tissue by nitration of salicylic acid 1. Commun Soil Sci Plant Anal 6: 71-80.

CHANDRA S, SINGH S \& KUMARI D. 2015. Evaluation of functional properties of composite flours and sensorial attributes of composite flour biscuits. J Food Sci Technol 52: 3681-3688.

CHEN GL, CHEN SG, CHEN F, XIE YQ, HAN MD, LUO C. X, ZHAO YY \& GAO YQ. 2016. Nutraceutical potential and antioxidant benefits of selected fruit seeds subjected to an in vitro digestion. J Funct Foods 20: 317-331.

CHIVANDI E, MUKONOWENZOU N \& BERLINER D. 2016. The coastal red-milkwood (Mimusops caffra) seed: Proximate, mineral, amino acid and fatty acid composition. S Afr J Bot 102: 137-141.

CLERICI MTPS, KALLMANN C, GASPI FOG, MORGANO MA, MARTINEZBUSTOS F \& CHANG YK. 2011. Physical, chemical and technological characteristics of Solanum lycocarpum A. 
St.-HILL (Solanaceae) fruit flour and starch. Food Res Int 44: 2143-2150.

CONAB - COMPANHIA NACIONAL DE ABASTECIMENTO. 2017. Boletim da Sociobiodiversidade. Volume 1, Número 1 - $1^{\circ}$ trimestre.

CONAB - COMPANHIA NACIONAL DE ABASTECIMENTO. 2019, Boletim da Sociobiodiversidade. Volume 3, Número 1 1 o trimestre.

COSTA FR, RÊGO ER, RÊGO MM, NEDER DG, DE MELO SS \& SCHUNEMANN APP. 2015. Análise biométrica de frutos de umbuzeiro do semiárido brasileiro. Biosci J 31: 682-690.

CUI SW, NIE S \& ROBERTS KT. 2011. Functional Properties of Dietary Fiber. In Moo-Yung M (Ed), Comprehensive Biotechnology. $2^{\text {nd }}$ ed,. Oxford: Academic Press Burlington, p. 517-525.

DAI FJ \& CHAU CF. 2017. Classification and regulatory perspectives of dietary fiber. J Food Drug Anal 25: 37-42.

DENCH JE, RIVAS R, \& CAYGILL JC. 1981. Selected functional properties of sesame (Sesamum indicum L.) flour and two protein isolates. J Sci Food Agric 32: 557-564.

DENG GF ET AL. 2012. Potential of fruit wastes as natural resources of bioactive compounds. Int J Mol Sci 13: 8308-8323.

DEPARTMENT OF HEALTH AND SOCIAL SECURITY. 1984. Nutritional aspects of cardiovascular disease. Report on Health and Social Subjects, n. 46, London: HMSO, 32 p

DORNI C, SHARMA P, SAIKIA G \& LONGVAH T. 2018. Fatty acid profile of edible oils and fats consumed in India. Food chem 238: 9-15.

EFSA - EUROPEAN FOOD SAFETY AUTHORITY. 2008. Opinion of the Scientific Panel on Contaminants in the Food chain on a request from the European Commission to perform a scientific risk assessment on nitrate in vegetables. EFSA J 689: 1-79.

ELLEUCH M, BEDIGIAN D, ROISEUX O, BESBES S, BLECKER C \& ATTIA H. 2011. Dietary fibre and fibre-rich by-products of food processing: Characterization, technological functionality and commercial applications: A review. Food Chem 124: 411-421.

FDA - FOOD AND DRUG ADMINISTRATION. 1993. Nutrient content claims for "good source," "high," and "more". Code of Federal Regulations, n. 101d, p. 84-85.

GILANI GS, XIAO CW \& COCKELL KA. 2012. Impact of antinutritional factors in food proteins on the digestibility of protein and the bioavailability of amino acids and on protein quality. Br J Nutr 108: S315-S332.
GONDIM JAM, MOURA MDF, DANTAS AS, MEDEIRO RLS, \& SANTOS KM. 2005. Composição centesimal e de minerais em cascas de frutas. Food Sci Technol (Campina) 25: 825-827. GREGORIS E, PEREIRA LIMA GP, FABRIS S, BERTELLE M, SICARI M \& STEVANATO R. 2013. Antioxidant properties of Brazilian tropical fruits by correlation between different assays. Biomed Res Int 2013, 8 p.

HASSIMOTTO NM, GENOVESE MI \& LAJOLO FM. 2005. Antioxidant activity of dietary fruits, vegetables, and commercial frozen fruit pulps. J Agric Food Chem 53: 2928-2935.

IAL - INSTITUTO ADOLFO LUTZ. 2008. Métodos físico-químicos para análise de alimentos. São Paulo: IAL, 120 p.

INADA KOP ET AL. 2015. Screening of the chemical composition and occurring antioxidants in jabuticaba (Myrciaria jaboticaba) and jussara (Euterpe edulis) fruits and their fractions. J Funct Foods 17: 422-433.

JACOMETTI GA, MELLO LR, NASCIMENTO PH, SUEIRO AC, YAMASHITA F \& MALI S. 2015. The physicochemical properties of fibrous residues from the agro industry. LWT-Food Sci Technol 62: 138-143.

KAKADE ML, RACKIS JJ, MCGHEE JE \& PUSKI G. 1974. Determination of trypsin inhibitor activity of soy products: a collaborative analysis of an improved procedure. Cereal Chem 51: 376-382.

KARAMAN E, YILMAZ E \& TUNCEL NB. 2017. Physicochemical, Microstructural and Functional Characterization of Dietary Fibers Extracted from Lemon, Orange and Grapefruit Seeds Press Meals. Bioact Carbohydr Diet Fibre 11: 9-17.

KOWALSKA H, CZAJKOWSKA K, CICHOWSKA J, \& LENART A. 2017. What's new in biopotential of fruit and vegetable byproducts applied in the food processing industry. Trends Food Sci Technol 67: 150-159.

KSOURI WM, MEDINI F, MKADMINI K, LEGAULT J, MAGNÉ C, ABDELLY C \& KSOURI R. 2013. LC-ESI-TOF-MS identification of bioactive secondary metabolites involved in the antioxidant, anti-inflammatory and anticancer activities of the edible halophyte Zygophyllum album Desf. Food Chem 139: 1073-1080.

KULCZYŃSKI B, GRAMZA-MICHAŁOWSKA A, KOBUS-CISOWSKA J \& KMIECIK D. 2017. The role of carotenoids in the prevention and treatment of cardiovascular disease-Current state of knowledge. J Funct Foods 38: 45-65.

LACHMAN J, HEJTMÁNKOVÁ A, TÁBORSKÝ J, KOTÍKOVÁ Z, PIVEC V, STŘALKOVÁ R, VOLLMANNOVA A, BOJANSKA T \& DĚDINA M. 2015. Evaluation of oil content and fatty acid composition in the seed of grapevine varieties. LWT-Food Sci Technol 6: 620-625. 
LAMAISON JLC \& CARNET A. 1990. Teneurs en principaux flavonoïdes des fleurs de Crataegeus monogyna Jacq et de Crataegeus laevigata (Poiret D.C) en fonction dela végétation. Pharm Acta Helv 65: 315-320.

LEÃO DP, FRANCA AS, OLIVEIRA LS, BASTOS R \& COIMBRA MA. 2017. Physicochemical characterization, antioxidant capacity, total phenolic and proanthocyanidin content of flours prepared from pequi (Caryocar brasilense Camb.) fruit by-products. Food Chem 225: 146-153.

LIN MJY, HUMBERT ES \& SOSULSKI FW. 1974. Certain functional properties of sunflower meal products. J Food Sci 39: 368-370.

LUZIA DM \& JORGE N. 2013. Bioactive substance contents and antioxidant capacity of the lipid fraction of Annona crassiflora Mart. seeds. Ind Crop Prod 42: 231-235.

MALLEK-AYADI S, BAHLOUL N \& KECHAOU N. 2017. Characterization, phenolic compounds and functional properties of Cucumis melo L. peels. Food Chem 221: 1691-1697.

MARTINS ZE, PINHO O \& FERREIRA IMPLVO. 2017. Food industry by-products used as functional ingredients of bakery products. Trends Food Sci Technol 67: 106-128.

MATOS FJA. 1997. Introdução à fitoquímica experimental. 2a ed., Fortaleza: edições UFC, 141 p.

MEDEL-MARABOLÍ M, ROMERO JL, OBREQUE-SLIER E, CONTRERAS A \& PEÑA-NEIRA, A. 2017. Effect of a commercial tannin on the sensorial temporality of astringency. Food Res Int 102: 341-347.

MELO EA \& ANDRADE RDS. 2010. Compostos bioativos e potencial antioxidante de frutos do umbuzeiro Bioactive compounds and antioxidant potential from the "umbuzeiro" fruits. In: Alimentos e Nutrição Araraquara, $2^{\text {nd }}$ ed., p. 453-458.

MMA - MINISTÉRIO DO MEIO AMBIENTE. 2020. Biomas/ Caatinga https://www.mma.gov.br/biomas/caatinga.

MOHAN VR, TRESINA PS, DAFFODIL ED. 2016. Antinutritional Factors in Legume Seeds: Characteristics and Determination. In: Caballero B et al. (Eds), Encyclopedia of Food and Health. Oxford: Academic Press. (Elsevier), p. 211-220.

MOURA FT, MELO SILVA S, SCHUNEMANN AP \& MARTINS LP. 2013. Frutos do umbuzeiro armazenados sob atmosfera modificada e ambiente em diferentes estádios de maturação. Rev Ciênc Agron 44: 764-772.

NetO EMDFL, PERONI N \& DE ALBUQUerque UP. 2010. Traditional knowledge and management of Umbu (Spondias tuberosa, Anacardiaceae): an endemic species from the semi-arid region of Northeastern Brazil Econ Bot 64: 11-21.

OKPALA LC \& GIBSON-UMEH GI. 2013. Physicochemical properties of mango seed flour. Niger Food J 31: 23-27.
PADOVANI RM, AMAYA-FARFÁN J, COLUGNATI, FAB \& DOMENE SMÁ. 2006. Dietary reference intakes: aplicabilidade das tabelas em estudos nutricionais. Rev Nutr 19: 741-760.

PEREIRA MG, HAMERSKI F, ANDRADE EF, SCHEER ADP \& CORAZZA ML. 2017. Assessment of subcritical propane, ultrasoundassisted and Soxhlet extraction of oil from sweet passion fruit (Passiflora alata Curtis) seeds. J Supercrit Fluids 128: 338-348.

PNUD. 2019. Programa das Nações Unidas para o Desenvolvimento: Fruto símbolo da caatinga, umbu gera desenvolvimento econômico no sertão do São Francisco (Posted on 25 de Abril de 2019). From: https:// www.br.undp.org/content/brazil/pt/home/presscenter/ articles/2019/fruto-simbolo-da-caatinga--umbu-geradesenvolvimento-economico-n.html.

PRICE ML, HAGERMAN AE \& BUTLER LG. 1980. Tannin content of cowpeas, chickpeas, pigeon peas, and mung beans. J Agr Food Chem 28: 459-461.

RAMFUL D, TARNUS E, ARUOMA OI, BOURDON E \& BAHORUN T. 2011. Polyphenol composition, vitamin C content and antioxidant capacity of Mauritian citrus fruit pulps. Food Res Int 44: 2088-2099.

RE R, PELLEGRINI N, PROTEGgente, A, PANNALA A, YANG M \& RICE-EVANS C. 1999. Antioxidant activity applying an improved ABTS radical cation decolorization assay. Free Radical Biol Med 26: 1231-1237.

REIS DS, FIGUEIREDO NETO A, FERRAZ AV \& DE FREITAS ST. 2017. Produção e estabilidade de conservação de farinha de acerola desidratada em diferentes temperaturas. Braz J Food Technol 20: 2015083.

RODRIGUEZ-AMAYA DB \& KIMURA M. 2004. Harvest Plus Handbook of Carotenoids Analysis. Washington, DC and Cali: International Food Policy Research Institute and International Center for Tropical Agriculture, 64 p.

ROUSK J, BROOKES PC \& BÅÅTH E. 2009. Contrasting soil $\mathrm{pH}$ effects on fungal and bacterial growth suggest functional redundancy in carbon mineralization. Appl Environ Microbiol 75: 1589-1596.

RUFINO MSM, ALVES RE, BRITO ES, PÉREZ-JIMÉNEZ J, SAURACALIXTO F \& MANCINI-FILHO J. 2010. Bioactive compounds and antioxidant capacities of 18 non-traditional tropical fruits from Brazil. Food Chem 121: 996-1002.

SELANI MM, SHIRADO GA, MARGIOTTA GB, SALDAÑA E, SPADA FP, PIEDADE SM, PIEDADE SMS, CONTRERAS-CASTILLO CJ \& CARNNIATTI-BRAZA SG. 2016. Effects of pineapple byproduct and canola oil as fat replacers on physicochemical and sensory qualities of low-fat beef burger. Meat Sci 112: 69-76.

SCHOFIELD P, MBUGUA DM \& PELL AN. 2001. Analysis of condensed tannins: a review. Anim Feed Sci Technol 91: 21-40. 
SERENO AB, BAMPI M, DOS SANTOS IE, FERREIRA SMR, BERTIN RL \& KRÜGER CCH. 2018. Mineral profile, carotenoids and composition of cocona (Solanum sessiliflorum Dunal), a wild Brazilian fruit. J Food Compos Anal 72: 32-38.

SILVA LMR, DE FIGUEIREDO EAT, RICARDO NMPS, VIEIRA IGP, DE FIGUEIREDO RW, BRASIL IM \& GOMES CL. 2014. Quantification of bioactive compounds in pulps and by-products of tropical fruits from Brazil. Food Chem 143: 398-404.

SINGLETON VL \& ROSSI JA. 1965. Colorimetry of total phenolics with phosphomolybdic-phosphotungstic acid reagents. Am J Enol Vitic 16: 144-158.

SKROVANKOVA S, SUMCZYNSKI D, MLCEK J, JURIKOVA T \& SOCHOR J. 2015. Bioactive compounds and antioxidant activity in different types of berries. Int J Mol Sci 16: 24673-24706.

SOSULSKI FN. 1962. The centrifugation method for determining flour absortion in hard red spring wheats. Cereal Chem 39: 344-350.

STROHECKER R \& HENNING HM. 1967. Analisis de vitaminas: metodos comprobados. Madrid: Paz Montalvo, $428 \mathrm{p}$.

WHITE PJ \& JOHNSON LA. 2003. Corn Chemistry and Technology. American Association of Cereal Chemists, St. Paul, MN.

WONG C. 2017. Iron deficiency anaemia. Pediatr Child Health 27: 527-529.

YOUNIS YMH, GHIRMAY S \& AL-SHIHRY SS. 2000. African Cucurbita pepo L.: properties of seed and variability in fatty acid composition of seed oil. Phytochem 54: 71-75.

ZAMBIAZI RC, PRZYBYLSKI R, ZAMBIAZI MW \& MENDONÇA CB. 2007. Fatty acid composition of vegetable oils and fats. Bol. Centro Pesqui Process Aliment 25: 111-120.

ZANOTTO DL \& BELLAVER C. 1996. Método de determinação da granulometria de ingredientes para uso em rações de suínos e aves. Embrapa/CNPSA, 1-5 p.

\section{How to cite}

XAVIER VL, FEITOZA GS, BARBOSA JML, ARAÚJO KS, SILVA MV, CORREIA MTS, SOUZA MP \& CARNEIRO-DA-CUNHA MG. 2022. Nutritional and technological potential of Umbu (Spondias tuberosa Arr. Cam.) processing by-product flour. An Acad Bras Cienc 94: e20200940. DOI 10.1590/0001-3765202220200940.

Manuscript received on June 19, 2020;

accepted for publication on August 30, 2020

VIVIANE L. XAVIER ${ }^{1,2^{*}}$

https://orcid.org/0000-0002-3661-6961

GEORGE S. FEITOZA ${ }^{1 *}$

https://orcid.org/0000-0001-8534-7334

\section{JULYANNE MARIA L. BARBOSA ${ }^{1}$}

https://orcid.org/0000-0003-2725-6682

KATARYNNA S. DE ARAÚJO3

https://orcid.org/0000-0002-7924-8054

\section{MÁRCIA V. DA SILVA 1}

https://orcid.org/0000-0002-2221-5059

MARIA TEREZA S. CORREIA

https://orcid.org/0000-0003-4920-9975

MARTHYNA P. DE SOUZA

https://orcid.org/0000-0002-8629-143X

\section{MARIA DAS GRAÇAS CARNEIRO-DA-CUNHA ${ }^{1,5}$}

https://orcid.org/0000-0002-7219-5527

${ }^{1}$ Universidade Federal de Pernambuco (UFPE), Departamento de Bioquímica, Av. Prof. Moraes Rego, s/n, Cidade Universitária, 50670-420 Recife, PE, Brazil ${ }^{2}$ Universidade Federal de Pernambuco (UFPE), Departamento de Nutrição, Av. Prof. Moraes Rego, 1235, Cidade Universitária, 50670-901 Recife, PE, Brazil

${ }^{3}$ Centro de Tecnologias Estratégicas do Nordeste (CETENE), Av. Prof. Luís Freire, 1, Cidade Universitária, 50740-545 Recife, PE, Brazil

${ }^{4}$ Universidade Federal de Campina Grande (UFCG), Unidade Acadêmica de Ciências Biológicas, s/n, Santa Cecília, 58700-970 Patos, PB, Brazil

${ }^{5}$ Universidade Federal de Pernambuco (UFPE), Laboratório de Imunopatologia Keizo Asami (LIKA), Av. Prof. Moraes Rego, s/n, Cidade Universitária, 50670-901 Recife, PE, Brazil

${ }^{*}$ Both authors contributed equally to article.

Correspondence to: Maria das Graças Carneiro-da-Cunha E-mail address:mgcc@ufpe.br,mgcc1954@gmail.com

\section{Author contributions}

MGCC, MPS, MVS, MTSC: Conceptualization; MVS: Data curation; MGCC, MPS: Formal analysis; MGCC, MPS, MVS, MTSC: Funding acquisition; VLX, GSF, JMLB, KSA: Investigation; VLX, GSF, MPS: Methodology; MGCC, MPS: Project administration; MGCC, MPS: Resources, Software; MGCC, MPS: Supervision; MGCC, MPS, MTSC: Validation; MGCC, MPS, MTSC: Visualization; VLX, GSF: Writing original draft; MGCC, MPS, MTSC, Writing - review \& editing.

\section{(cc) BY}

